hens did not "set well," it is impossible to determine the exact cause of this high mortality.

The failure of these eggs to control lice is probably due to the fact that naphthalene vapor is over four times heavier than air and, therefore, does not work up through the feathers, although, as previously mentioned, a certain amount is taken into the hen's body, probably from direct contact with the egg.

It might be added that in many of the tests the nests and even the naphthalene eggs themselves were found to be swarming with chicken mites (D. gallino Redi.).

\title{
SUMmary
}

1. Powders containing 5 per cent or less of naphthalene are of no value against lice.

2. Powders containing from 10 per cent to 20 per cent are very effective.

3. As little as 10 per cent naphthalene may temporarily injure hens, if the powder is well rubbed in, and 60 per cent or more may kill the treated fowls under the same conditions.

4. Naphthalene (60 to 100 per cent) sprinkled over the backs of fowls at roost proved to be of considerable value against lice.

5. Naphthalene nest eggs are of no value against lice on laying or setting hens.

6. The data obtained indicate that setting hens, the eggs and possibly any chickens hatched are injured by these eggs.

\section{THE DEPLUMING MITE OF CHICKENS: ITS COMPLETE ERADICATION FROM A FLOCK BY ONE TREATMENT}

By H. P. Wood, U. S. Bureau of Entomology

During the course of experiments with the control of poultry lice a few flocks infested with the depluming mite ${ }^{1}$ were encountered. ${ }^{2}$ Inasmuch as treatments heretofore have consisted merely of ointments applied to the parts visibly affected, it was deemed worth while to attempt to find a method of completely destroying the mites in an infested flock. After a few preliminary experiments we were fortunate in discovering a method which has obtained the desired results.

The depluming mite is found in a scale surrounding the base of the feathers. To discover the mite on infested fowls it is only necessary

\footnotetext{
${ }^{1}$ Known scientifically as Cnemidocoptes gallina Railliet.

${ }^{2}$ This investigation was carried out at the Dallas, Texas, laboratory of the Bureau of Entomology, under the direction of Mr. F. C. Bishop.
} 
to pluck a few feathers from several regions of the fowl and examine with a lens the scales around the base of the quill. The head of the mite may be seen projecting slightly through the scale which is removed with the feather. This scale is larger than on a normal feather. It is often more difficult to find them on broken feathers than on whole feathers for the live mites are more often found on the whole feathers. Though in bad infestations either live or dead ones may be found on any feathers. As many as three adults have been found in one scale.

The adult female gives birth to larvæ still encased in the egg sack, the larva extricating itself from the egg sack soon after birth. Mites were found on feathers taken from back, top of wing, near vent, breast and thighs but none from tail or primary or secondary wing feathers. In the tunnel with a female were found thirty-one larvæ.

The damage to the plumage is very evident. Infested fowls have a ragged appearance with a good many broken feathers or perhaps bare spots. This appearance is more evident in the summer and fall than it is soon after molting. It is quite evident that any damage done to plumage would be detrimental to show birds. We believe also that more injury is done to poultry generally by this mite than is commonly supposed. There seems to be some itching which may result in feather pulling, causing some hens to become quite bare. The time fowls spend in combating this pest would better be spent in resting or getting food, thus producing increased growth or larger egg yield.

This mite seems to be quite generally distributed, according to reports of various authors. We have collections from Texas, and Mr. O. G. Babcock has sent us collections from Tennessee, Missouri and Mississippi. Even in infested districts, however, many flocks appear to be entirely free from the mites.

The following substances were tried out in preliminary control experiments: Lime-sulphur, potassium sulphuret, tobacco-sulphur, dry sulphur, arsenical dip (B. A. I. formula, white arsenic $8 \mathrm{lbs}$., sal soda 24 lbs., pine tar 1 gal., and water to make 500 gallons), kerosene emulsion, sulphur and sodium fluoride, sodium fluoride, soap and water, sulphur, soap and sodium fluoride. Sodium fluoride was included in the last two formulse to see if both lice and the depluming mite could be killed in one treatment.

Lime-8ulphur: One lb. lime, 2 lbs. sulphur, 1 gal. water. Dilution, 1 to 20 parts water. Fourteen days after treatment no live mites could be found; all lice were not killed.

Potassium 8Ulphuret: One-half oz. soap, $\frac{1}{2}$ oz. potassium sulphuret, 1 gal. water. Sixteen days after treatment some mites found alive.

Toвacco-sulphur: Three teaspoonfulls "Black Leaf $40, " 6$ ozs. sulphur, $2 \frac{1}{2}$ gal. water. Eleven days after treatment no live mites or lice found.

Dry sulphur: Thoroughly dusted with flowers of sulphur. Twelve days after treatment no live mites found. 
Arsenical Dip (B. A. I. formula): Made about three months, exact strength at time used not known. Fifteen days after treatment no live mites found.

Kenosene emolsion: Two gals. kerosene, $\frac{1}{2} \mathrm{lbs}$. soap, 1 gal. water. Dilution, 1 to 10 . Thirty-nine days after treatment no live mites found but fowl's skin was injured by burning.

SUlphUR AND sodium Fldoride: Two-thirds oz. NaF., 2 ozs. sulphur, 1 gal. water. Five days after treatment one live mite found. A later observation should have been made.

SOdIUM fluoride, SOAP and water: Three-fourths oz. NaF, $\frac{1}{2}$ oz. whale oil soap, 1 gal. water. Sixteen days after treatment live mites found.

SOdiUM FLUORIDE, SUlphUR, SOAP aNd Water: Two-thirds oz. NaF., 2 ozs. sulphur, soap (enough to make the water soapy), 1 gal. water. Sixteen days after treatment no live mites found.

In these experiments one hen was used in each experiment. The birds were held under the solution about one minute, during which time the feathers were thoroughly ruffled and the heads ducked two or three times.

Summary of Preliminary Experiments in Depltming Mite Control Substance Used All Mites Killed Injurious Effect

Lime-sulphur. Yes None

Potassium sulphuret................... No None

Tobacco-sulphur..................... Yes None

Dry sulphur............................ Yes

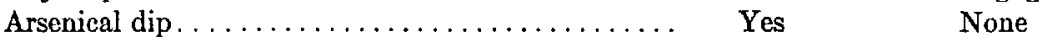

Kerosene emulsion................... Yes Injurious

Sulphur and sodium fluoride.............. No No None

Sodium fluoride, sulphur and soap........... Yes None

Of these substances, lime-sulphur, tobacco-sulphur, dry sulphur, B. A. I. Dip, and sodium fluoride, sulphur and soap were effective. Inasmuch as we have found sodium fluoride so effective against lice we thought it advisable to try on a larger scale to see if both the lice and depluming mite could be eradicated at one treatment.

June 30, 1917, 48 fowls infested with lice and the depluming mite were dipped in a solution of sodium fluoride (chemically pure) $\frac{2}{3}$ oz., sulphur $2 \mathrm{oz}$., soap (laundry) $\frac{1}{3} \mathrm{oz}$. (about), water 1 gal. A number of feathers were plucked from the treated fowls 27 days, 55 days, and about 5 months, $6 \frac{1}{2}$ months, 11 months, $1 \frac{1}{3}$ years after treatment and at no time were living mites or lice found.

A warm day was selected to treat the fowls and there was no injury to them. The experiment may, therefore, be considered, a complete success. A subsequent experiment on 120 hens infested with depluming mites, treated June 5, 1918, in the same way as in the above experiment and observed until January 17, 1919, verified the results of the previous experiment. 